\title{
Selection and characterisation of a phage-displayed human antibody (Fab) reactive to the lung resistance-related major vault protein
}

\author{
GL Scheffer', AW Reurs', B Jutten², SHW Beiboer², R van Amerongen', M Schoester ${ }^{3}$, EAC Wiemer ${ }^{3}$, \\ HR Hoogenboom ${ }^{2}$ and RJ Scheper,
}

'Department of Pathology, Free University Medical Center, De Boelelaan II I, I08I HV, Amsterdam, The Netherlands; ${ }^{2}$ Department of Pathology,

Maastricht University, Maastricht, The Netherlands; ${ }^{3}$ Institute of Hematology, Erasmus University, Rotterdam, The Netherlands

The major vault protein is the main component on multimeric vault particles, that are likely to play an essential role in normal cell physiology and to be associated with multidrug resistance of tumour cells. In order to unravel the function of vaults and their putative contribution to multidrug resistance, specific antibodies are invaluable tools. Until now, only conventional major vault protein-reactive murine monoclonal antibodies have been generated, that are most suitable for immunohistochemical analyses. The phage display method allows for selection of human antibody fragments with potential use in clinical applications. Furthermore, cDNA sequences encoding selected antibody fragments are readily identified, facilitating various molecular targeting approaches. In order to obtain such human Fab fragments recognising major vault protein we used a large nonimmunized human Fab fragment phage library. Phages displaying major vault protein-reactive Fabs were obtained through several rounds of selection on major vault protein-coated immunotubes and subsequent amplification in TGI $E$ coli bacteria. Eventually, one major vault protein-reactive clone was selected and further examined. The anti-major vault protein Fab was found suitable for immunohistochemical and Western blot analysis of tumour cell lines and human tissues. BIAcore analysis showed that the binding affinity of the major vault protein-reactive clone almost equalled that of the murine anti-major vault protein Mabs. The cDNA sequence of this human Fab may be exploited to generate an intrabody for major vault proteinknock out studies. Thus, this human Fab fragment should provide a valuable tool in elucidating the contribution(s) of major vault protein/vaults to normal physiology and cellular drug resistance mechanisms.

British Journal of Cancer (2002) 86, 954-962. DOl: 10.1038/sj/bjc/6600I59 www.bjcancer.com

(C) 2002 Cancer Research UK

Keywords: LRP; MVP; multidrug resistance; Fab; phage display.

Multidrug resistance (MDR; reviewed in Schneider et al, 1999) is a phenomenon frequently observed in tumour cells that are unresponsive to anti-cancer drugs. Proteins which can be involved in this process are the ATP-binding Cassette $(\mathrm{ABC})$ transporter proteins (Higgins, 1992) P-glycoprotein (P-gp, ABCB1; reviewed in Ambudkar et al, 1999), multidrug resistance protein 1 (MRP1, $\mathrm{ABCC} 1$ ), MRP2 (ABCC2), MRP3 (ABCC3; reviewed in Borst et $a l, 2000)$ and breast cancer resistance protein (BCRP, ABCG2; Doyle et al, 1998), as well as the lung resistance-related protein (LRP; Scheffer et al, 2000). LRP was identified as the major vault protein (MVP), the main component of vaults (Scheffer et al, 1995).

Vaults are large multimeric barrel-shaped particles that are highly conserved through evolution, and likely to play an essential role in normal cell physiology. They are composed of multiple copies of three proteins $(240,193$ and $104 \mathrm{kDa}$ in size) and unique untranslated RNA species. The $104 \mathrm{kDa}$ subunit is termed the MVP as it constitutes $>70 \%$ of the particle mass. The p240 minor vault protein is identical to the telomerase-associated protein (TEP1) (Kickhoefer et al, 1999a), a structural protein in

*Correspondence: Professor RJ Scheper; E-mail: rj.scheper@vumc.n Received 7 September 200 I; accepted II December 200I the telomerase complex. The other high molecular weight minor vault protein, $\mathrm{p} 193$, is a poly (ADP-ribose) polymerase (PARP) and is therefore named VPARP, for vault-PARP (Kickhoefer et al, 1999b).

The hollow structure of vaults is consistent with a role in either the compartmentalisation of macromolecular assemblies or in subcellular transport. In multidrug resistant tumour cells up-regulation of human $L R P / M V P$ mRNA and protein as well as vault particle copy number was observed (Scheper et al, 1993; Laurencot et al, 1997; Kickhoefer et al, 1998). Primary evidence for a direct causal relationship between LRP/MVP expression and drug resistance was provided by Kitazono et al (1999). They showed that reduction of $L R P / M V P$ expression by use of LRP/MVP-specific ribozymes in a cell line induced to overexpress $L R P / M V P$ by exposing cells to sodium butyrate was enough to prevent drug resistance. Still, these studies have to be confirmed by independent investigations.

In order to further study the function of vaults and their contribution to MDR, specific antibodies are essential. Several MVPreactive murine monoclonal antibodies (Mabs) are now available. These Mabs were all produced by classical hybridoma technology. In the past years the technology of display on filamentous phage in combination with selection was developed into a powerful tool for the identification of antibodies of human origin (Marks et al, 
1991; Winter et al, 1994; Hoogenboom et al, 1998). Partially or completely human antibodies are of particular interest as they are expected to elicit no or minimal immune responses when administered to patients. For the construction of antibody libraries, $\mathrm{V}$-genes are amplified from B-cell cDNA, and heavy and light chain genes are randomly combined and cloned to encode a combinatorial library of single-chain variable fragments $(\mathrm{scFv})$ or Fab antibody fragments (Clackson et al, 1991; Hoogenboom et al, 1991). Large non-immune human antibody libraries, made for example from the variable region genes of the B-cells of healthy individuals, have been used to select antibodies to a large panel of antigens, including self-, non-immunogenic- and relatively toxic antigens (Marks et al, 1991; de Haard et al, 1999). When using the phage display system, the cDNA of antibodies of interest becomes available without further cloning steps. In this study we used a large nonimmunised human Fab fragment phage library described by de Haard et al (1999) to isolate a human Fab reactive to the MVP.

\section{MATERIALS AND METHODS}

\section{Escherichia coli strain}

Escherichia coli TG1: K12, D(lac-pro), supE, thi, hsdD5/F' traD36, proA $^{+} \mathrm{B}^{+}$, lacl ${ }^{\mathrm{q}}$, lacZDM15.

\section{Selection of phages displaying anti-MVP human Fab}

For the selection of phages expressing anti-MVP Fab fragments a large non-immunised human Fab fragment phage library was used which was described by de Haard et al (1999). The library contains cDNA sequences, encoding highly diverse $\mathrm{Fab}$ fragments $\left(3.7 \times 10^{10}\right)$ with additional $\mathrm{c}-m y c$ and His tags, cloned in the phagemid vector pCES1.

Selection of phages was essentially according to published methods (Marks et al, 1991) on immunotubes (Nunc maxisorp; Life Technologies, Merelbeke, Belgium) coated overnight at $37^{\circ} \mathrm{C}$ with $20 \mu \mathrm{g}$ recombinant full-length MVP (Schroeijers et al, 2000) in $2 \mathrm{ml}$ coating buffer $(0.05 \mathrm{M}$ sodium carbonate, $\mathrm{pH}$ 9.6). Unbound antigen was removed and the tubes were blocked for $1 \mathrm{~h}$ with PBS/ $2 \%$ skimmed milk powder $/ 0.05 \%$ Tween 20 (MT-PBS). One ml of the page stock solution containing approximately $1 \times 10^{13}$ phages was diluted $1: 1$ in MT-PBS and allowed to bind to the antigen-coated immunotube for $2 \mathrm{~h}$ at room temperature. Unbound phages were washed off by 20 washes with PBS $/ 0.05 \%$ Tween 20 followed by 20 washes with PBS. Antigen-bound phages were eluted off, using $1 \mathrm{ml}$ freshly prepared $100 \mathrm{mM}$ triethylamine (TEA) for $10 \mathrm{~min}$. The solution was neutralised by adding $0.5 \mathrm{ml}$ of Tris buffer ( $1 \mathrm{M}, \mathrm{pH} 7.4)$. The solution was incubated for another hour at room temperature on immunotubes coated only with block buffer, to remove aspecifically bound phages. Unbound, antigen-specific phages were used to infect exponentially growing $\left(\mathrm{OD}_{600}\right.$ of 0.5$)$ TG1 bacteria, for $30 \mathrm{~min}$ at $37^{\circ} \mathrm{C}$. After infection, the bacteria were allowed to grow overnight at $30^{\circ} \mathrm{C}$ and glycerol stocks were made. To have an indication of the phage input/output ratio, titrations of the bacteria, immediately after infection, were plated on selective $2 \times \mathrm{TY}$ ( $16 \mathrm{~g}^{-1}$ trypton, $10 \mathrm{~g} \mathrm{l}^{-1}$ yeast extract and $5 \mathrm{~g} \mathrm{l}^{-1} \mathrm{NaCl}$ ) plates supplemented with $2 \%$ glucose and $100 \mu \mathrm{g} \mathrm{ml}^{-1}$ ampicillin. The plates were incubated overnight at $30^{\circ} \mathrm{C}$ and colonies were counted the following day. For the next selection round, a sufficient amount of bacteria to ensure the presence of at least 10 bacteria of each clone, was inoculated in $50 \mathrm{ml} 2 \times \mathrm{TY}$ medium containing $100 \mu \mathrm{g} \mathrm{ml}^{-1}$ ampicillin and $2 \%$ glucose, giving a start $\mathrm{OD}_{600}$ of approximately 0.05 . Five $\mathrm{ml}$ of bacteria grown at $37^{\circ} \mathrm{C}$ to an $\mathrm{OD}_{600}$ of 0.5 were infected with $2 \mu \mathrm{l} \mathrm{M13-K07} \mathrm{helper} \mathrm{phage} \mathrm{(approximately} 1 \times 10^{13}$ phages per $\mathrm{ml}$ ) for $30 \mathrm{~min}$ at $37^{\circ} \mathrm{C}$. The bacteria were spun down, resuspended in $50 \mathrm{ml}$ of $2 \times \mathrm{TY}$ medium containing $100 \mu \mathrm{g} \mathrm{ml}^{-1}$ ampicillin and $25 \mu \mathrm{g} \mathrm{ml}^{-1}$ kanamycin to select for super-infected bacteria, and grown overnight at $30^{\circ} \mathrm{C}$. The bacteria were spun down, the selected phages secreted into the supernatant were precipitated twice using 1/5th volume 20\% PEG 6000; $2.5 \mathrm{M} \mathrm{NaCl}$, resuspended in $1 \mathrm{ml}$ of PBS and used in the next selection round on antigen coated immunotubes. A total of four, essentially identical selection rounds was carried out on MVP-coated immunotubes.

\section{Screening of individual phage clones}

To select individual phage clones displaying MVP-reactive Fabs, single bacterial colonies were grown at small-scale overnight at $30^{\circ} \mathrm{C}$ in $2 \times \mathrm{TY} / 2 \%$ glucose $/ 100 \mu \mathrm{g} \mathrm{ml}^{-1}$ ampicillin in U-shaped 96-well plates (Costar, Corning, NY, USA). These plates were kept as 'master plates' at $-80^{\circ} \mathrm{C}$ after adding glycerol to a final concentration of $15 \%$. Then, $1: 100$ dilutions of the bacterial colonies were grown for $2 \mathrm{~h}$ at $37^{\circ} \mathrm{C}$ in $\mathrm{V}$-shaped 96-well plates (Costar). Phages displaying recombinant $\mathrm{Fab}$ were produced by adding $25 \mu$ l of $1: 250$ diluted helper phage stock solution. Supernatants containing phages were tested for reactivity in recombinant MVP coated ELISA plates. ELISA plates were coated overnight at $37^{\circ} \mathrm{C}$ with $100 \mu \mathrm{l}, 5 \mu \mathrm{g}$ MVP per $\mathrm{ml}$ coating buffer $(0.05 \mathrm{M}$ sodium carbonate, $\mathrm{pH}$ 9.6). Plates were rinsed, blocked with $200 \mu \mathrm{l} \mathrm{PBS/}$ $1 \%$ BSA $/ 0.05 \%$ Tween 20 and incubated with phage-containing supernatant for $1 \mathrm{~h}$ at room temperature. Bound phages were detected using an in-house produced guinea pig-anti-phage polyclonal antiserum $(1: 1000)$ and HRP-labelled swine-anti-guinea pig antiserum (1:500, Dako, Copenhagen, Denmark). Colour development was with 5-amino-2-hydroxybenzoic acid (5-AS; Merck, Darmstadt, Germany) and $0.02 \% \mathrm{H}_{2} \mathrm{O}_{2}$ as a chromogen.

\section{Large-scale production of Fab fragments}

Large-scale induction of soluble Fabs from individual clones was performed on a $50 \mathrm{ml}$ scale in $2 \times \mathrm{TY}$ medium, containing $100 \mu \mathrm{g} \mathrm{ml}^{-1}$ ampicillin and $2 \%$ glucose. The bacteria were grown at $37^{\circ} \mathrm{C}$ to an $\mathrm{OD}_{600}$ of 0.9 . The cells were pelleted, resuspended in $50 \mathrm{ml} 2 \times \mathrm{TY}$, containing $100 \mu \mathrm{g} \mathrm{ml}^{-1}$ ampicillin and $1 \mathrm{mM}$ isopropyl-1-thio- $\beta$-D-galactopyranoside (IPTG) to activate the $\mathrm{LacZ}$ promoter, and grown for $4 \mathrm{~h}$ at $30^{\circ} \mathrm{C}$. Soluble Fabs were purified making use of the His-tag on Ni-NTA-superflow agarose beads according to the manufacturer's protocol (Qiagen Inc., CA, USA).

\section{BstNI fingerprinting}

Individual bacterial colonies were used for standard 40 cycle hotstart PCR reactions, using fd-tet-seq24 (5'-TTT GTC GTC TTT CCA GAC GTT AGT-3') as a forward and M13-reverse (5'-AGC GGA TAA CAA TTT CAC ACA GG-3') as a reverse primer. The resulting amplimers were digested with Bst $\mathrm{NI}$ and loaded onto a $2 \%$ agarose gel. The banding pattern of the clones was analysed on a UV transluminator.

\section{Sequence analysis}

Plasmids from individual bacterial clones were sequenced using the dideoxy sequencing method on a semi-automated sequencer (Alf Express, Pharmacia, Uppsala, Sweden). CH1 for (5'-GTC CTT GAC CAG GCA GCC CAG GGC-3') and M13 reverse (5'-AGC GGA TAA CAA TTT CAC ACA GG-3') were used as forward and reverse primers, respectively. $\mathrm{V}$-gene sequences were aligned to V-BASE (http://www.mrc-cpe.cam.ac.uk/imt-doc/ public/INTRO.html).

\section{Immunoprecipitation}

Cells were trypsinised and lysed in PBS containing 1\% NP40, $1 \mathrm{mM}$ EDTA, $1 \mathrm{~mm}$ phenylmethylsulphonyl fluoride (PMSF) for $2 \mathrm{~min}$ at room temperature, followed by a boost with an ultra-sound finger. 
Large fragments and nuclei were removed by centrifugation at 9000 g. Clear supernatant was pre-incubated for $30 \mathrm{~min}$ with protein Asepharose beads to reduce non-specific binding of labelled protein. Cell lysate supernatants or solutions containing approximately $10 \mu \mathrm{g}$ recombinant MVP were incubated with $10 \mu \mathrm{l}$ soluble Fab or, as a control, $10 \mu \mathrm{g}$ of LRP-56 MAb $2 \mathrm{~h}$ at room temperature. To the Fab precipitation $100 \mu \mathrm{l}$ of anti-c-myc mouse monoclonal antibody 9E10 was added and incubation was continued for another hour. Then $50 \mu \mathrm{l}$ of prot A-sepharose beads $(\sim 25 \mu \mathrm{l}$ 'packed beads') was added and precipitation was allowed for $1 \mathrm{~h}$. Precipitates were washed three times in lysis buffer and three times in PBS. Antibody-antigen interaction was broken by dispensing the beads in Western blot loading buffer, containing $200 \mathrm{~mm}$ Tris-HCl ( $\mathrm{pH}$ 6.8), 1\% $\beta$-mercaptoethanol, $8 \%$ SDS, $10 \%$ glycerol and $0.05 \%$ bromophenol blue.

\section{Western blot analysis}

Total cell lysates were made as described (Zaman et al, 1994). Protein concentrations were determined with a BioRad protein assay (BioRad, Richmond, CA, USA). Cell lysates $(10-40 \mu \mathrm{g})$ or $2 \mu \mathrm{g}$ recombinant MVP or immunoprecipitates were fractionated on a $8 \%$ polyacrylamide slab gel and transferred onto a nitrocellulose membrane by electroblotting. After blocking, the membrane was incubated for $2 \mathrm{~h}$ with anti-MVP Fab in an appropriate dilution. HRP-labelled rabbit-anti-human lambda chain $(1: 200$, Dako) was used as a secondary antibody. Colour development was with $0.5 \mathrm{~g} \mathrm{l}^{-1} \quad 3,3^{\prime}$-diamino-benzidine tetrahydrochloride, $0.15 \mathrm{~g} \mathrm{l}^{-1}$ chloronaphthol and $0.02 \% \mathrm{H}_{2} \mathrm{O}_{2}$ in PBS.

\section{BIAcore analysis}

The affinity of the anti-MVP antibodies was further examined by surface plasmon resonance on a BIAcore 2000 instrument (Biacore $\mathrm{AB}$, Uppsala, Sweden). Recombinant fusion protein of MVP and glutathione-S-transferase (GST-MVP; Schroeijers et al, 2000) was immobilised on the flow cell of an activated CM-5 sensorchip according to the manufacturer's protocol (Biacore $\mathrm{AB}$ ), yielding a surface of 2000 resonance units. Soluble Fab fragments and control murine Mabs were analysed at room temperature, at a flow rate of $25 \mu \mathrm{l}$ per minute, using HBS-EP (Biacore AB, 0.01 M HEPES, $\mathrm{pH} 7.4,0.15 \mathrm{M} \mathrm{NaCl}, 3 \mathrm{mM}$ EDTA, $0.005 \%$ polysorbate 20 ) as a buffer. Dissociation rates were calculated from the sensorgrams using the BIA-evaluation software (Biacore AB).

\section{Immunohistochemistry}

Cytospin preparations and cryosections $(4 \mu \mathrm{m})$ were air dried overnight and fixed at room temperature for $7 \mathrm{~min}$ in $100 \%$ acetone or for $10 \mathrm{~min}$ in $3 \%$ paraformaldehyde $/ 0.3 \%$ glucose. For detection of MVP with MVP-37 Mab and human Fab MVP$\varphi 4$, the slides were pretreated with $6 \mathrm{~N}$ guanidine hydrochloride Fab MVP- $\varphi 4$, the slides were pretreated with $6 \mathrm{~N}$ guanidine hydrochloride $(\mathrm{GdnHCl})$ in $50 \mathrm{~mm}$ Tris- $\mathrm{HCl}(\mathrm{pH} \mathrm{7.5)}$ for $10 \mathrm{~min}$ at room temperature, as described (Schroeijers et al, 2000). The slides were incubated with primary antibody for $1 \mathrm{~h}$ at room temperature or at $37^{\circ} \mathrm{C}$ for the $\mathrm{GdHCl}$ treated slides. Biotinylated rabbit-antimouse (1:150, Zymed, San Francisco, CA, USA) and HRP-labelled streptavidin $(1: 500$, Zymed) were used as secondary reagents for the mouse Mabs. For detection of the human Fab, 1:10 diluted anti-c-myc-tag 9E10 Mab, and HRP-labelled rabbit-anti-mouse serum (1:500, Dako, Copenhagen, Denmark) was used.

Colour development was with $0.4 \mathrm{mg} \mathrm{ml}^{-1}$ amino-ethyl-carbazole (AEC) and $0.02 \% \mathrm{H}_{2} \mathrm{O}_{2}$ as a chromogen.

\section{Cell lines}

The lung cancer cell lines SW1573 (parent), SW1573/2R120 (MVP and MRP1 positive), SW1573/2R160 (MDR1 P-gp positive and a low percentage of MVP positive cells) were described in reference (Kuiper et al, 1990). The lung cancer cell lines GLC4 (parent) and GLC4/ADR (MVP and MRP1 positive) were described in reference (Zijlstra et al, 1987). All cell lines were grown in Dulbecco's modified essential medium (Gibco Europe, Paisley, Scotland), supplemented with $10 \%$ heat-inactivated foetal calf serum, $2 \mathrm{mM} \mathrm{L}$ glutamine, penicillin and streptomycin. Resistant cell lines were cultured in the presence of drugs until 3-10 days before the experiments. All cells were negative for Mycoplasma as tested by the Gene-Probe rapid Mycoplasma detection system (Gene-Probe, San Diego, CA, USA).

\section{Antibodies}

Murine anti-MVP Mabs used were LRP-56 (Scheper et al, 1993), LMR-5 (Flens et al, 1997), MVP-9, MVP-16, MVP-37 (Schroeijers et al, 2001) and LRP (Transduction Laboratories, Lexington, KY, USA).

The anti-c-myc mouse Mab 9E10 was described in Chan et al (1987). The guinea pig-anti-phage polyclonal antiserum was produced by immunizing guinea pigs with wild type M13-K07 helper phages suspended in Freund's complete adjuvant (Difco, Detroit, MI, USA). Two booster injections with phages in PBS were given. Serum was collected and used without further purification.

\section{RESULTS}

\section{Selection of anti-MVP human Fab}

The successive rounds to select anti-MVP human Fabs on immunotubes coated with recombinant MVP, showed a gradual increase in the amount of antigen bound phages (output number). When the output number of round one was set to 1 , output numbers of 50,500 and 10000 were noted for round 2, 3 and 4, respectively (Table 1). Apparently, the cycles of selection and reamplication yielded increasing numbers of antigen-binding phages. ELISA screening of approximately 750 individual clones from round 2, 3 and 4, resulted in the identification of several MVPreactive phages. The percentage of antigen binding phages per selection round is depicted in Table 1. Twenty-two individual MVP-reactive clones from round 3 and 4 were selected for BstNI fingerprinting. These clones all showed a very similar banding

Table I Enrichment of MVP binding phages per selection round

\begin{tabular}{|c|c|c|c|c|c|}
\hline $\begin{array}{l}\text { Input phages } \\
10^{13} \text { per } \mathrm{ml}\end{array}$ & $\begin{array}{l}\text { Output } \\
\text { phages }\end{array}$ & $\begin{array}{l}\text { Input/output } \\
\text { ratio }\end{array}$ & $\begin{array}{l}\text { Enrichment } \\
\text { per round }\end{array}$ & $\begin{array}{l}\text { Enrichment } \\
\text { factor }\end{array}$ & $\begin{array}{l}\text { Recombinant MVP } \\
\text { ELISA positives }\end{array}$ \\
\hline Ist round & $1 \times 10^{4}$ & $1 \times 10^{9}$ & & 1 & \\
\hline 2nd round & $5 \times 10^{5}$ & $2 \times 10^{7}$ & 50 & 50 & $0 / 48$ \\
\hline 3rd round & $5 \times 10^{6}$ & $2 \times 10^{6}$ & 10 & 500 & $15 / 224$ \\
\hline 4th round & $1 \times 10^{8}$ & $1 \times 10^{5}$ & 20 & 10000 & $18 / 440$ \\
\hline
\end{tabular}




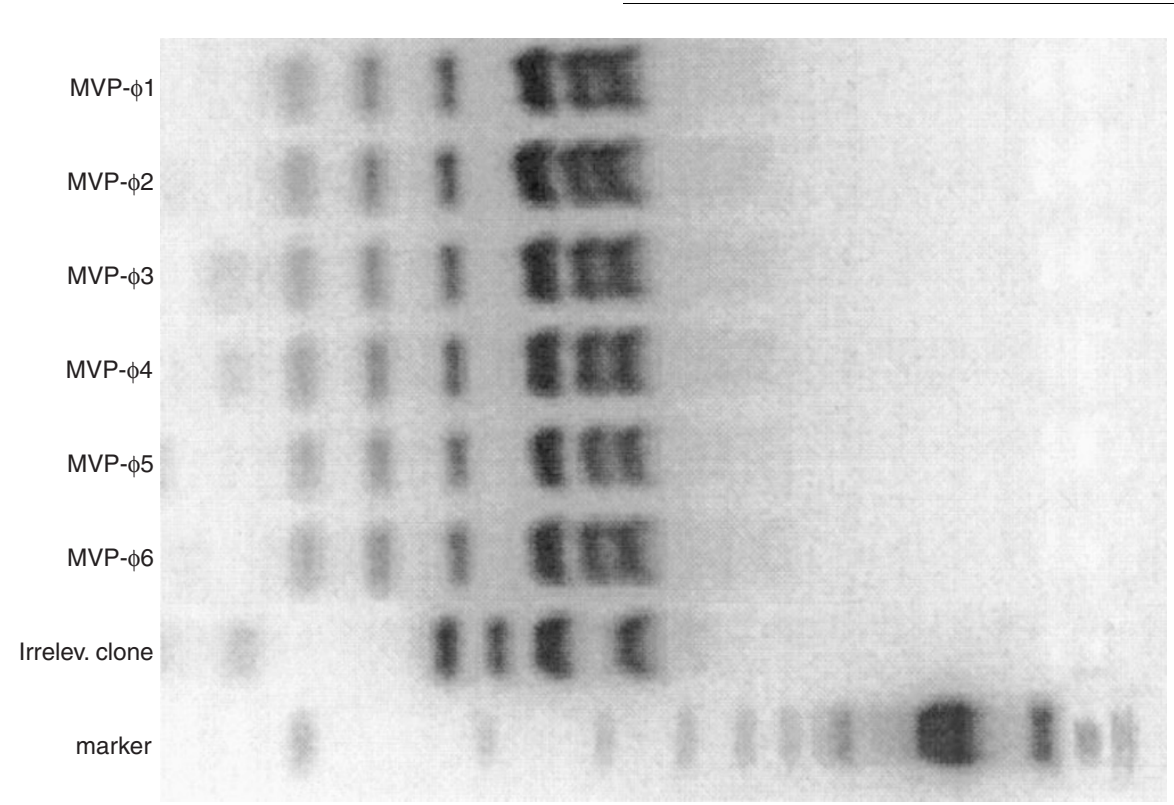

Figure I BstNI fingerprinting of six MVP-reactive clones from selection rounds 3 and 4 and a randomly selected non-reactive clone. cDNA of individual clones was PCR amplified, BstNI digested and loaded on an agarose gel. The MVP-reactive clones all show a very similar banding pattern, strikingly different from the irrelevant clone.

\begin{tabular}{|c|c|c|}
\hline EMBL & Locus & Name \\
\hline Z12366 & $4-61$ & $D P-66 / V 71-2 \ldots+$ \\
\hline$X 56356$ & - & VH4.12 \\
\hline X92230 & - & 4.39 \\
\hline Z12371 & $4-59$ & DP-71/3d197d ... \\
\hline M29812 & $4-59$ & V71-4+ \\
\hline EMBL & Locus & Name \\
\hline 212366 & $4-61$ & DP-66/V71-2 $\ldots+$ \\
\hline$\times 56356$ & - & $\mathrm{VH} 4.12$ \\
\hline X92230 & - & 4.39 \\
\hline Z12371 & $4-59$ & DP-71/3d197d...+ \\
\hline M29812 & 4-59 & V71-4+ \\
\hline EMBL & Locus & Name \\
\hline Z12366 & $4-61$ & DP-66/V71-2... \\
\hline$x 56356$ & - & VH 4.12 \\
\hline$\times 92230$ & - & 4.39 \\
\hline 212371 & $4-59$ & DP-71/3d197d ... \\
\hline M29812 & $4-59$ & V71-4+ \\
\hline EMBL & Locus & Name \\
\hline 212366 & $4-61$ & DP-66/V71-2 ..+ \\
\hline$\times 56356$ & - & $\mathrm{VH} 4.12$ \\
\hline X92230 & - & 4.39 \\
\hline 212371 & $4-59$ & DP-71/3d197d,..+ \\
\hline M29812 & $4-59$ & V71-4+ \\
\hline
\end{tabular}

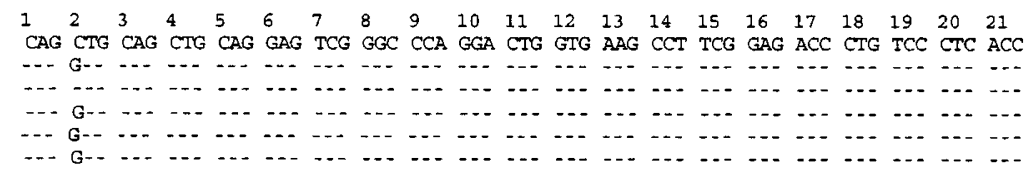

H1

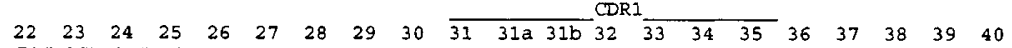
TGC AGT GTC TCT GGT GGC TCC ATC AGC AGT GGT GGT TAC TAC TGG AGC TGG ATC CGC CAG CGC

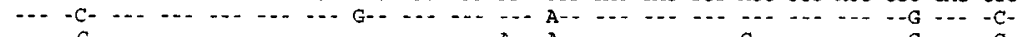

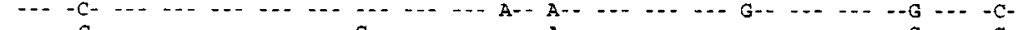

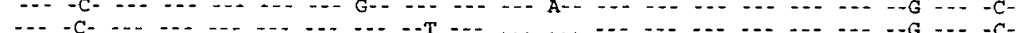

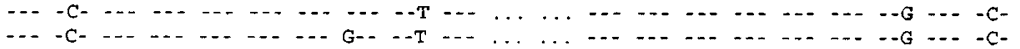

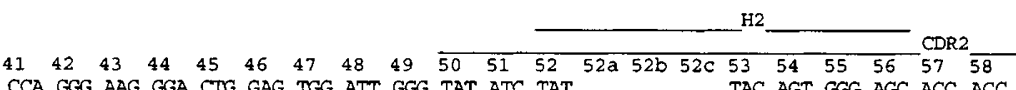
CCA GGG AAG GGA CTG GAG TGG ATT GGG TAT ATC TAT ... $. . .1 . .$. TAC AGT GGG AGC ACC ACC

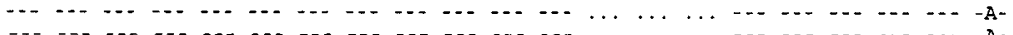

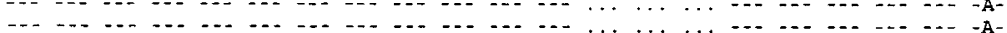
$\begin{array}{llllllll}0 & -\end{array}$

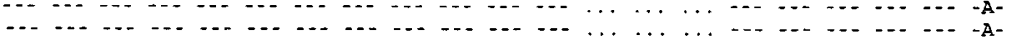

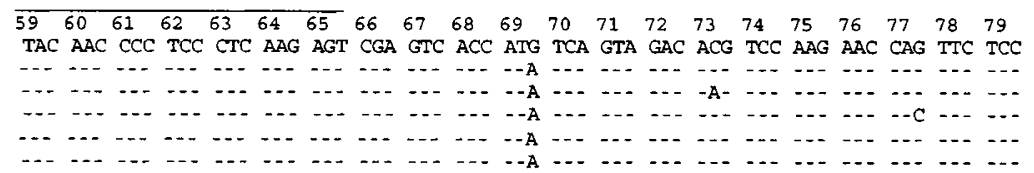

$\begin{array}{lllllllllllllllllll}80 & 81 & 82 & 82 \mathrm{a} & 82 \mathrm{~b} & 82 \mathrm{c} & 83 & 84 & 85 & 86 & 87 & 88 & 89 & 90 & 91 & 92 & 93 & 94 & \overline{95}\end{array}$ CTG AAG CTG AGC TCT GTG ACC GCC GCA GAC ACG GCC TTT TAT TAC TGT GCG AGA CAA CTG AAG CTG AGC TCT GTG ACC GCC GCA GAC ACG GCC TIT TAT TAC TGT GCG AGA CAA [..

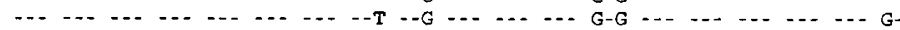

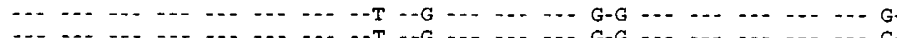

score TGTGCGAGACAAGGGGTCTACTACTACTACGGTATGGACGTCTGGGGCCAAGGGACCACGGTCACCGTCTCAAGC

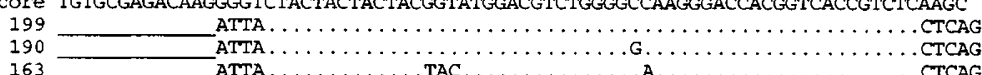

Figure 2 Comparison of the obtained heavy chain cDNA sequence of the anti-MVP Fab MVP- $\varphi 4$ (accession number AJ306838) with V-BASE. The Fab uses a heavy chain belonging to the VH4 family. Highest homology was observed to germline clone DP-66/V7I-2...+. The antigen specific CDR3 sequences for the heavy chain are: QGVYYYYGMDV. The number of amino acid changes from the germline, excluding the CDR3 region, is eight. 


$\begin{array}{lll}\text { EMBL } & \text { Locus } & \text { Name } \\ \text { Z73673 } & 6 \text { a } & 6 \mathrm{a} .366 \mathrm{F5} / \mathrm{V} 1-22 \ldots+ \\ \text { X73642 } & \text { 2d } & \text { 2d.29D11/DPL13... } \\ \text { L27692 } & - & \text { lv2113 } \\ \text { L27697 } & - & \text { Iv216.21 } \\ \text { Z73657 } & \text { 2e } & 2 \mathrm{e} .2 .2 / \mathrm{V} 1-3+\end{array}$

$\begin{array}{lllllllllllllllllllll}1 & 2 & 3 & 4 & 5 & 6 & 7 & 8 & 9 & 11 & 12 & 13 & 14 & 15 & 16 & 17 & 18 & 19 & 20 & 21 & 22\end{array}$ AAT TTT ATG CTG ACT CAG CCC CAC TCT GTG TCG GAG TCT CCG GGG AAG ACC ATA ACC ATC TCC

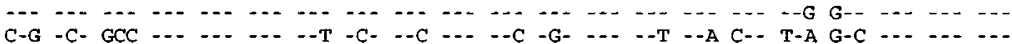

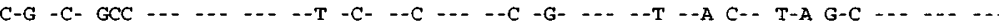
C-G -C- GCC -.. -.. -.. - - T -C- -.

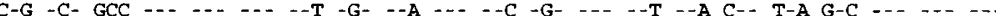

$\begin{array}{lll}\text { EMBL } & \text { Locus } & \text { Name } \\ \text { Z73673 } & 6 \mathrm{a} & 6 \mathrm{a} .366 \mathrm{~F} 5 / \mathrm{V} 1-22 \ldots+ \\ \text { X73642 } & 2 \mathrm{~d} & \text { 2d.29D11/DPL13... } \\ \text { L27692 } & - & \text { lv2113 } \\ \text { L27697 } & - & \text { lv216.21 } \\ \text { Z73657 } & \text { 2e } & 2 \mathrm{e} .2 .2 / \mathrm{V} 1-3+\end{array}$

CDRI

$23 \begin{array}{llllllllllllllllllllllll}24 & 25 & 26 & 27 & 28 & 29 & 30 & 31 & 31 \mathrm{a} & 31 \mathrm{~b} & 31 \mathrm{C} & 32 & 33 & 34 & 36 & 37 & 38 & 39 & 40\end{array}$ TGC ACC CGC AGC AGT GGC AGC ATT GGC AGC AAT ... TAT GTG TAC TGG TAC CAG CAG CGC CCG

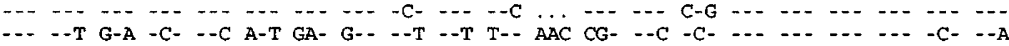

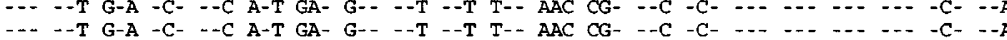

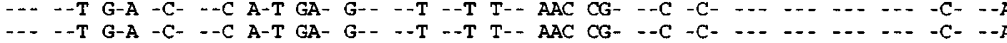
$\ldots-$ -

$\begin{array}{lll}\text { EMBL } & \text { Locus } & \text { Name } \\ \text { Z73673 } & 6 \mathrm{a} & 6 \mathrm{a} .366 \text { F5 } / \mathrm{V} 1-22 \ldots+ \\ \text { X73642 } & \text { 2d } & 2 \mathrm{~d} .29 \mathrm{D} 11 / \mathrm{DPL} 13 \ldots+ \\ \text { L27692 } & - & \text { lv2113 } \\ \text { L27697 } & - & \text { lv216.21 } \\ \text { Z73657 } & \text { 2e } & 2 \mathrm{e} .2 .2 / \mathrm{VI}-3+\end{array}$

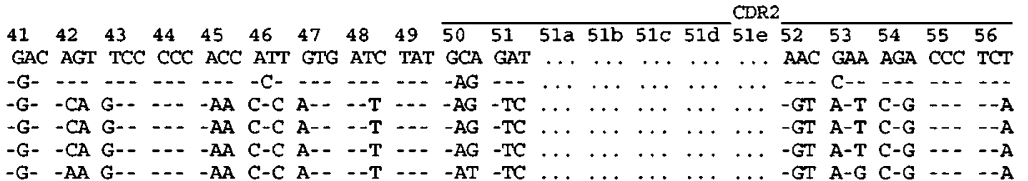

$\begin{array}{lll}\text { EMBL } & \text { Locus } & \text { Name } \\ \text { Z73673 } & 6 \mathrm{a} & 6 \mathrm{a} .366 \mathrm{F5} / \mathrm{VI}-22 \ldots+ \\ \text { X73642 } & 2 \mathrm{~d} & 2 \mathrm{~d} .29 \mathrm{D} 11 / \mathrm{DPL} 13 \ldots+ \\ \text { L27692 } & - & \text { lv2113 } \\ \text { L27697 } & - & \text { lv216.21 } \\ \mathrm{Z73657} & \text { 2e } & 2 \mathrm{e} .2 .2 / \mathrm{V} 1-3+\end{array}$

$\begin{array}{lllllllllllllllllllll}57 & 58 & 59 & 60 & 61 & 62 & 63 & 64 & 65 & 66 & 67 & 68 & 68 \mathrm{a} & 68 \mathrm{~b} & 69 & 70 & 71 & 72 & 73 & 74 & 75\end{array}$ GGG GTC CCT GGT CGG TTC TCT GGC TCC ATC GAC AGC TCC TCC AAC TCT GCC TCC CTC ACC ATC

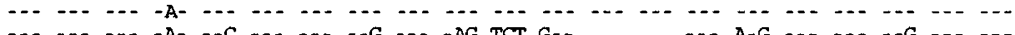

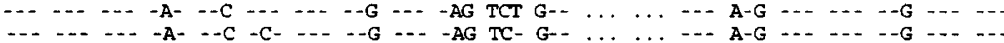
-. $\ldots$

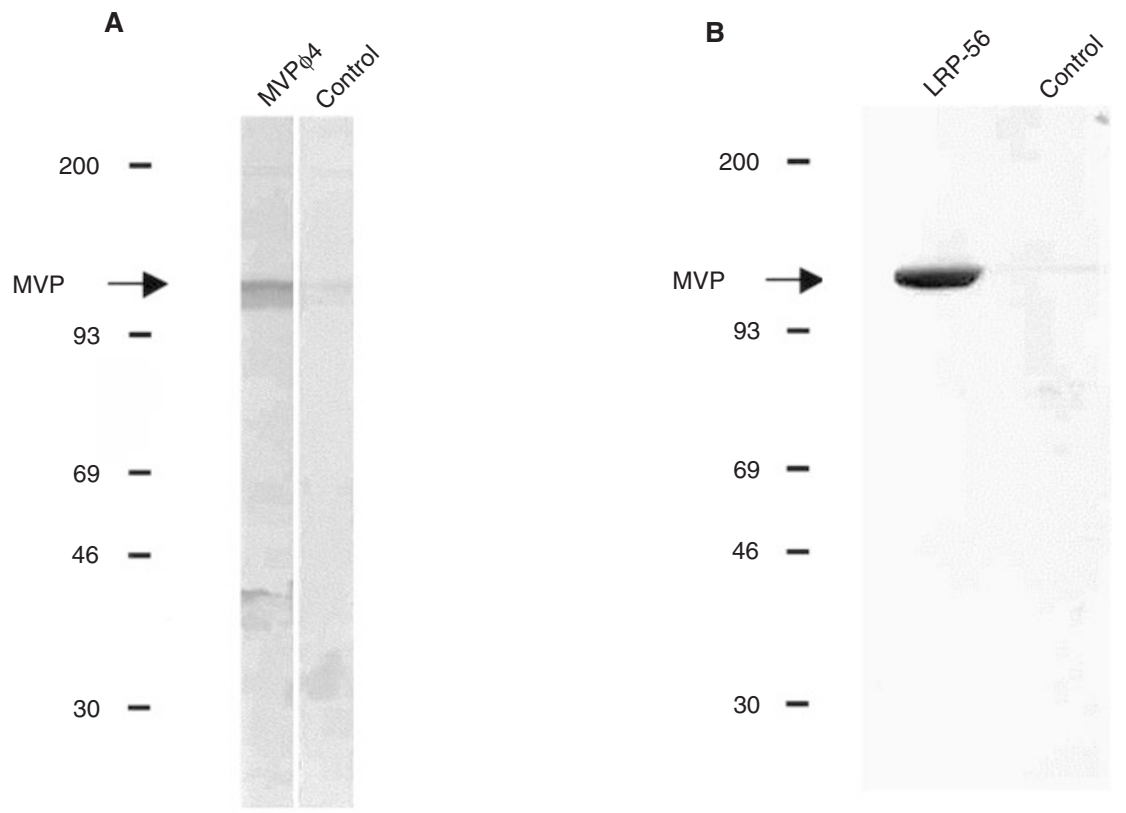

Figure 4 Western blots of cell lysates of MVP-overexpressing GLC4 ADR cells $(\mathbf{A})$ and the immunoprecipitation products of the anti-MVP mouse Mab LRP-56 (B; left lane) or a control Mab (B; right lane) from a cell lysate of the GLC4 ADR cells. Proteins were loaded, separated and blotted. Blots were incubated with MVP- $\varphi 4$ (A, left lane and $\mathbf{B}$ ) or a control Fab (A, right lane) followed by HRP-labelled rabbit-anti-human lambda chain. Colour development was with $\mathrm{DAB} / \mathrm{chloronaphthol} / \mathrm{H}_{2} \mathrm{O}_{2}$. On both blots, MVP- $\varphi 4$ was reactive with the MVP protein at the expected $\mathrm{M}_{r}$ of I I0000 (arrow). 
pattern, that was strikingly different from a randomly selected nonreactive clone (Figure 1). Sequence analysis of six of these clones confirmed that they were all identical. One clone, named MVP$\varphi 4$, was used for further characterization studies. The sequences of the heavy and light chain variable regions of the MVP- $\varphi 4$ clone are available under accession numbers AJ306838 and AJ306837, respectively, at the EMBL database.

\section{Heavy and light chain usage of the anti-MVP Fab}

Comparison of the obtained cDNA sequence of the anti-MVP Fab with V-BASE showed that the Fab uses a heavy chain belonging to the VH4 family and a light chain belonging to the VL6 family (Figures 2 and 3). Highest homology was observed to germline clones DP-66/V71-2...+ (heavy chain) and 6a.366F5/V1-22..+ (light chain). The antigen specific CDR3 sequences for the heavy and light chain are: QGVYYYYGMDV and QSYSNNKWI, respectively. The number of amino acid changes from the germline, excluding the CDR3 region, is eight for the heavy chain and 10 for the light chain.

\section{Reactivity of anti-MVP Fab in Western blots and immunoprecipitation}

In Western blots of cell lysates of MVP-overexpressing GLC4 ADR cells, MVP- $\varphi 4$ was reactive with the MVP protein at the expected $\mathrm{M}_{r}$ of 110000 (Figure 4A). Furthermore, MVP- $\varphi 4$ was able to detect the $\mathrm{M}_{r} 110000$ immunoprecipitation product of the anti-MVP mouse Mab LRP-56 and a cell lysate of the GLC4 ADR cells in the same test system (Figure 4B). Also, the recombinant MVP could be detected in similar Western blot experiments (not shown).

In immunoprecipitation experiments, the anti-MVP Fab was unable to precipitate the MVP protein from either $M V P$-overexpressing GLC4 ADR cells or recombinant MVP in solution (not shown). These results indicate that MVP- $\varphi 4$ is reactive to a linear or more denatured epitope of the MVP molecule. Of note, the LRP-56 mouse Mab is reactive to a more native epitope, judged from its reactivity in the immunoprecipitation experiments (see Figure 4B), and its inability to react with MVP in Western blots. Also, LRP-56 is unreactive with recombinant MVP coated in ELISA plates (not shown).

\section{BIAcore analysis of anti-MVP Mabs and MVP- $\varphi 4$}

The off-rates of several murine anti-MVP Mabs and MVP- $\varphi 4$ were determined by surface plasmon resonance on a BIAcore 2000 instrument, with recombinant GST - MVP immobilised on the flow cell of a CM-5 sensorchip, giving a surface of 2000 resonance units. As anticipated, the LRP-56 and LMR-5 Mabs were unreactive with MVP presented in this way, but the other available (bivalent) murine Mabs MVP-9, MVP-16, MVP-37, LRP were reactive with the MVP molecule immobilised on the chip (Figure 5). These, and the monovalent MVP- $\varphi 4$ human Fab, gave off-rates of $1.3 \times 10^{-3}, 1.4 \times 10^{-2}, 1.3 \times 10^{-4}, 5.2 \times 10^{-5}$, and $1.3 \times 10^{-3}$, $\mathrm{s}^{-1}$, respectively.

\section{Reactivity of anti-MVP Fab on cytospins and tissue sections}

A panel of cell lines with known presence or absence of MVP was stained with MVP- $\varphi 4$. MVP- $\varphi 4$ was only very moderately reactive on preparations of cell lines fixed with $100 \%$ acetone. However, using the guanidine fixation method (see Materials and methods), which facilitates detection of more denatured epitopes, the antiMVP Fab showed the presence of MVP in GLC4 ADR cells, SW1573/2R120 cells and in an earlier identified small subpopulation of cells of the MDR1 P-gp positive SW1573/2R160 cell line (Figure 6A). Essentially similar results were obtained in control stainings with MVP-37, using the same treatment, or with LRP$56 \mathrm{Mab}$ on acetone fixed cytospins. Further confirmation of the specificity of the anti-MVP Fab was obtained in studying human tissue staining. Using guanidine-treated, frozen sections of human lung tissue, MVP- $\varphi 4$ was found to be reactive with MVP in the epithelial cells of the bronchi (Figure 6B). Again, comparable staining results were seen in the control stainings with MVP-37 and LRP-56.

\section{DISCUSSION}

For the detection of MVP and transmembrane transporter molecules mediating MDR several conventionally produced murine Mabs have become available. The phage display method allows selection of human antibody fragments, which are expected to elicit less or no immune responses when administered in humans. Using

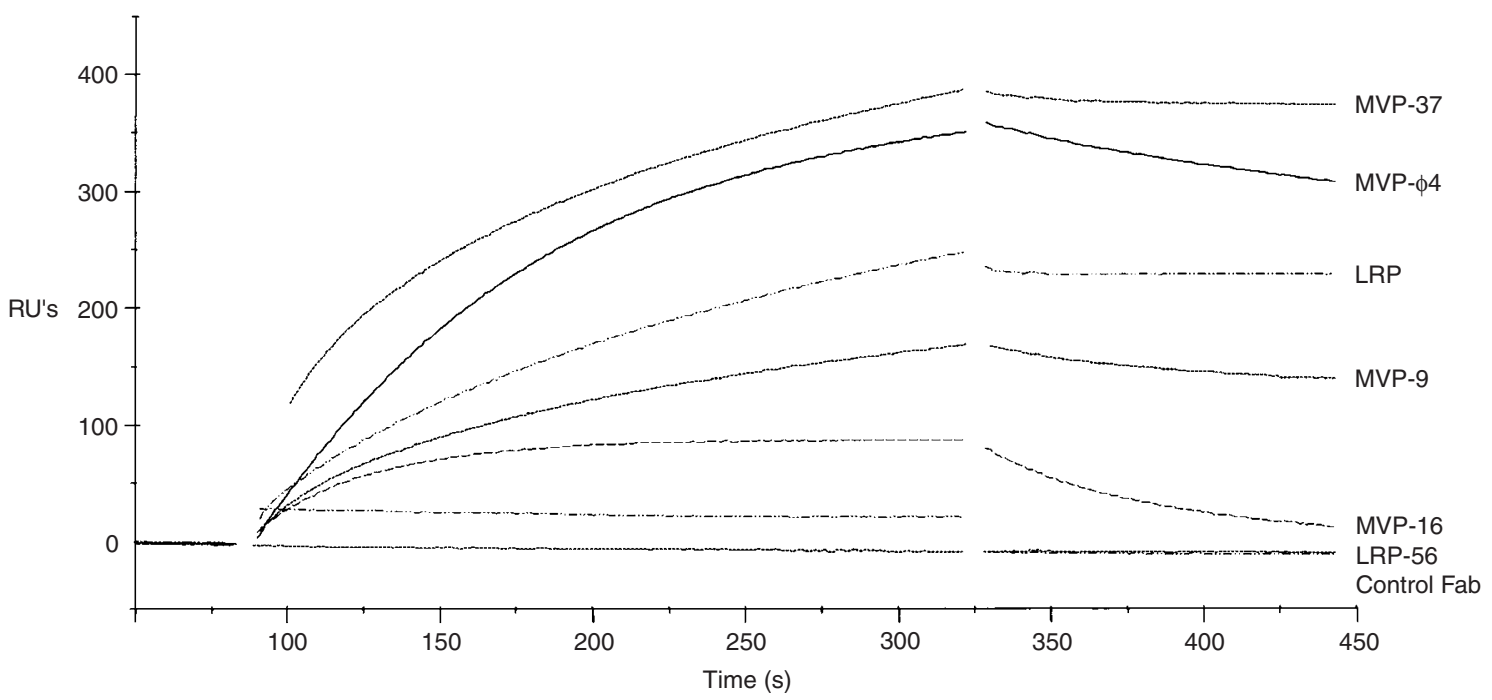

Figure 5 BIAcore analysis of the anti-MVP reagents. The off-rate of several murine anti-MVP Mabs and MVP- $\varphi 4$ was determined by surface plasmon resonance on a BIAcore 2000 instrument, with recombinant GST-MVP immobilised on the flow cell of a CM-5 sensorchip. The control Fab and LRP$56 \mathrm{Mab}$ (and LMR-5, not shown) were un-reactive in this system. The other murine Mabs MVP-9, MVP-I6, MVP-37, LRP and the MVP- $\varphi 4$ human Fab showed differential reactivity to the MVP molecule immobilised on the chip. 
A
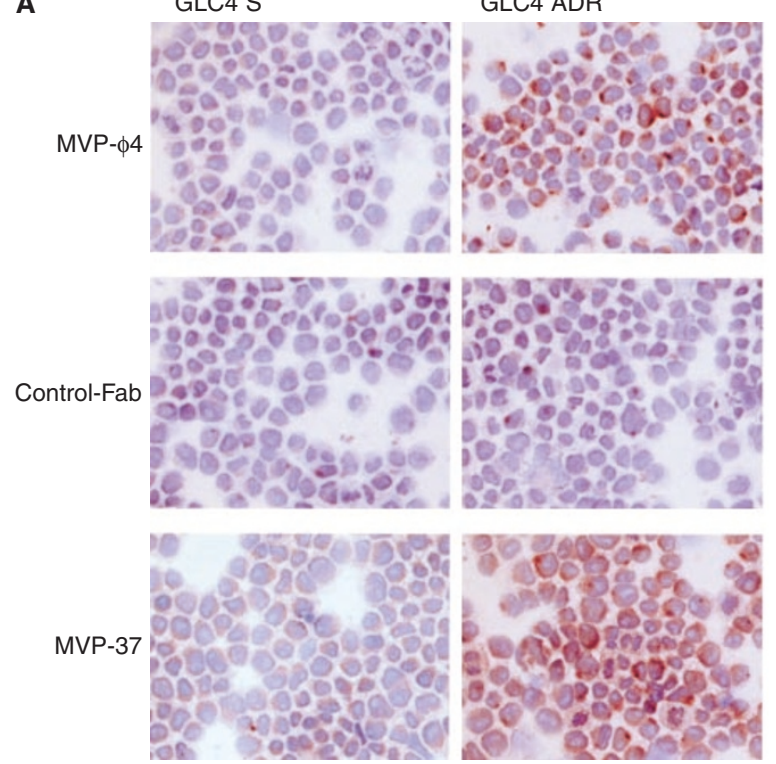

SW1573/2R160
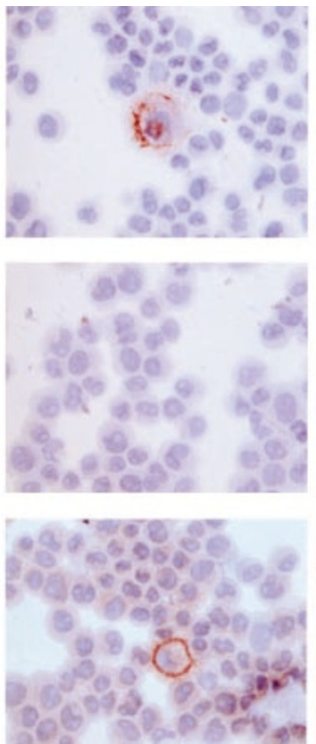

SW1573/2R120
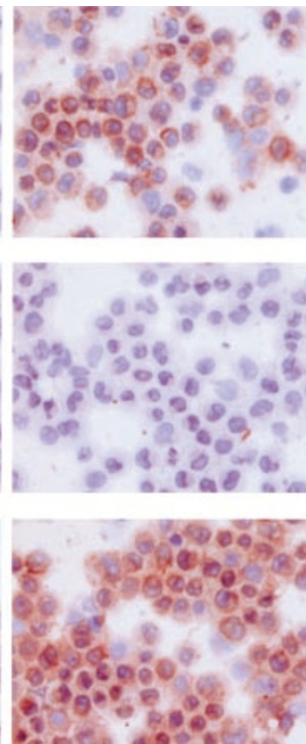

B

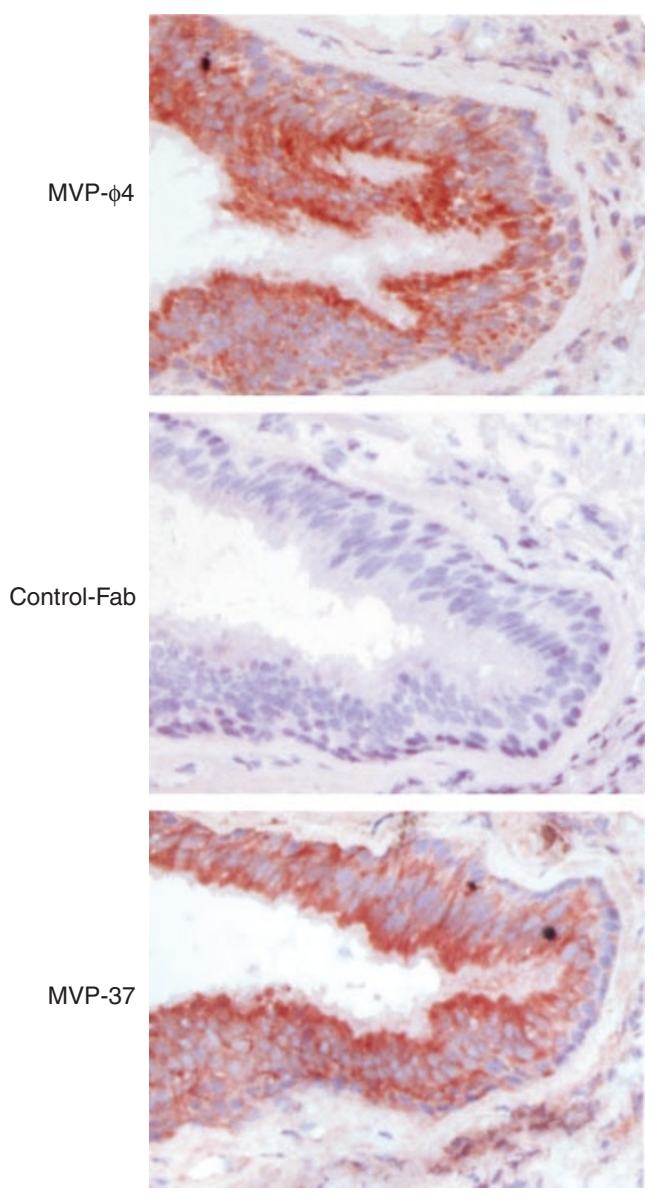

Figure 6 Staining results for MVP in a panel of cell lines with known presence or absence of MVP $(\mathbf{A})$ and in frozen sections of normal human lung (B). Preparations were pretreated using the guanidine method (see Materials and methods) and stained with MVP- $\varphi 4$, control Fab or MVP-37 murine Mab. Biotinylated rabbit-anti-mouse and HRP-labelled streptavidin were used as secondary reagents for the mouse Mab. For detection of the human Fabs, $9 E I O M a b$ and HRP-labelled rabbit-anti-mouse serum was used. Colour development was with $\mathrm{AEC} / \mathrm{H}_{2} \mathrm{O}_{2}$. Both the anti-MVP Fab MVP- $\varphi 4$ and the murine Mab MVP-37 show, as expected, the presence of MVP in the GLC4 ADR cells, the SWI573/2RI 20 cells and in a characteristic low percentage of cells in the MDRI P-gp positive SW 1573/2RI 60 cells (A). Furthermore, MVP- $\varphi 4$ and MVP-37 show the presence of MVP in the epithelial cells of the bronchi of the lung (B). 
this new technology various human antibodies have now been generated, and some of these have already entered phase III clinical applications (Holliger and Hoogenboom, 1998; Vaughan et al, 1998). Up till now, for none of the molecules associated with MDR these type of human antibodies have been generated. Only for MDR1 P-gp humanised versions of the monoclonal antibodies MRK16 (Hamada et al, 1990) and MRK17 (Ariyoshi et al, 1992) have been constructed. Also, the phage display method has been used successfully to identify peptide epitopes of MDR1 P-gp Mabs (Poloni et al, 1995a,b) and peptides mimicking the drug-binding activity of P-gp (Popkov et al, 1998). The present selection of a human anti-MVP reactive Fab by the phage display method is, therefore, the first report on truly human antibodies in this field.

During the selection steps of the anti-MVP Fab, successive selection rounds yielded increasing numbers of MVP-specific Fabs. However, BstNI fingerprint and sequence analyses showed that eventually only one type of Fab was isolated. The selection of just one type of Fab may have resulted from the way the selections were performed, causing loss of low affinity phages, e.g. due to low amounts of antigen for selection and high stringency conditions at the elution steps. Also, utilising recombinant MVP as the selection antigen, that may not have full native conformation, and the apparent presence of selection-dominant epitopes in most antigens (Hoogenboom et al, 1999) may have influenced the outcome of the selections. On the other hand, although the presently used library has been successfully applied for isolating Fabs against rare antigens and self antigens (de Haard et al, 1999), it cannot be excluded that these results still reflect library limitations.

In any case, the isolated MVP- $\varphi 4$ Fab performed very well in several immunohistochemical and Western blot applications. The immunohistochemical results were optimal when the cytospins and tissues were pretreated with denaturing guanidine $/ \mathrm{HCl}$ solution. These results, and the unreactivity of the Fab in immunoprecipitation experiments, suggest its reactivity with a linear epitope of the MVP molecule. Of note, both LRP-56 and LMR-5 Mabs are likely to react with more native epitopes, as judged from their good performance in immunoprecipitation experiments, in

\section{REFERENCES}

Ambudkar SV, Dey S, Hrycyna CA, Ramachandra M, Pastan I, Gottesman MM (1999) Biochemical, cellular, and pharmacological aspects of the multidrug transporter. Ann Rev Pharmacol Toxicol 39: 361 - 398

Ariyoshi K, Hamada H, Naito M, Heike Y, Seimiya H, Maezawa K, Tsuruo T (1992) Mouse-human chimeric antibody MH171 against the multidrug transporter P-glycoprotein. Jpn J Cancer Res 83: 515-521

Borst P, Evers R, Kool M, Wijnholds J (2000) A family of drug transporters: the multidrug resistance-associated proteins. J Natl Cancer Inst 92: 1295 1302

Chan S, Gabra H, Hill F, Evan G, Sikora K (1987) A novel tumour marker related to the c-myc oncogene product. Mol Cell Probes 1: 73-82

Clackson T, Hoogenboom HR, Griffiths AD, Winter G (1991) Making antibody fragments using phage display libraries. Nature 352: 624-628

de Haard HJ, van Neer N, Reurs A, Hufton SE, Roovers RC, Henderikx P, de Bruine AP, Arends JW, Hoogenboom HR (1999) A large non-immunized human Fab fragment phage library that permits rapid isolation and kinetic analysis of high affinity antibodies. J Biol Chem 274: 18218-18230

Deshane J, Loechel F, Conry RM, Siegal GP, King CR, Curiel DT (1994) Intracellular single-chain antibody directed against erbB2 down-regulates cell surface erbB2 and exhibits a selective anti-proliferative effect in erbB2 overexpressing cancer cell lines. Gene Ther 1: 332-337

Doyle LA, Yang WD, Abruzzo LV, Krogmann T, Gao YM, Rishi AK, Ross DD (1998) A multidrug resistance transporter from human MCF-7 breast cancer cells (erratum in PNAS USA 1999; 96(5): 2569). Proc Natl Acad Sci USA 95: $15665-15670$

Flens MJ, Scheffer GL, van der Valk P, Broxterman HJ, Eijdems EW, Huysmans AC, Izquierdo MA, Scheper RJ (1997) Identification of novel drug resistance-associated proteins by a panel of rat monoclonal antibodies. Int J Cancer 73: 249-257 the absence of Western blot reactivity. Interestingly, BIAcore analyses showed that the MVP- $\varphi 4 \mathrm{Fab}$, as a monovalent fragment, has a relatively slow off-rate $\left(1.3 \times 10^{-3}, \mathrm{~s}^{-1}\right)$, as frequently observed with conventional antibodies generated from a secondary immune response. Indeed, the MVP- $\varphi 4$ Fab off-rate was within the range observed for other (bivalent) murine anti-MVP Mabs.

The present identification of an MVP-specific Fab may allow for the construction of plasmids for functional knock-out purposes. The cDNA encoding the Fab can be transferred to an eukaryotic expression plasmid which may also provide a fusion between the $\mathrm{Fab}$ and an endoplasmatic reticulum retention signal. Transfection of this new construct into MVP-positive tumour cells then might lead to blockage of the MVP protein, e.g. due to binding of the Fab to the epitope during protein synthesis, and thus interfere with vault assembly and/or function. Recently, the expression of only the MVP molecule in Sf9 insect cells was shown to be sufficient for the assembly of vault-like particles (Stephen et al, 2001). Targeting this critical vault component, therefore, is very likely to result in the knock-out of functional vault particles. Analogous applications of 'intrabodies' have already been described for e.g. erbB-2 (Deshane et al, 1994), Ras (Lener et al, 2000), huntingtin (LeCerf et al, 2001), as well as the anti-P-gp directed C219 ScFv (Heike et al, 2001).

In conclusion, a human Fab fragment reactive to MVP, named MVP- $\varphi 4$, was isolated by phage display technology. This Fab may become a valuable tool in studying the contribution of MVP and vaults to normal physiology and MDR.

\section{ACKNOWLEDGEMENTS}

This work was supported in part by Koningin Wilhelmina Fonds (KWF) grant EUR 98-1754 to EAC Wiemer and RJ Scheper and by the Netherlands Technology Foundation (STW), grant MGN55.3858, 805.17.753 to SHW Beiboer and HR Hoogenboom.

Hamada H, Miura K, Ariyoshi K, Heike Y, Sato S, Kameyama K, Kurosawa Y, Tsuruo T (1990) Mouse-human chimeric antibody against the multidrug transporter P-glycoprotein. Cancer Res 50: 3167 - 3171

Heike Y, Kasono K, Kunisaki C, Hama S, Saijo N, Tsuruo T, Kuntz DA, Rose DR, Curiel DT (2001) Overcoming multi-drug resistance using an intracellular anti-MDR1 sFv. Int J Cancer 92: 115-122

Higgins CF (1992) ABC transporters - from microorganisms to man. Ann Rev Cell Biol 8: $67-113$

Holliger P, Hoogenboom H (1998) Antibodies come back from the brink. Nat Biotechnol 16: 1015-1016

Hoogenboom HR, de Bruine AP, Hufton SE, Hoet RM, Arends JW, Roovers RC (1998) Antibody phage display technology and its applications. Immunotechnology 4: $1-20$

Hoogenboom HR, Griffiths AD, Johnson KS, Chiswell D, Hudson P, Winter G (1991) Multi-subunit proteins on the surface of filamentous phage: methodologies for displaying antibody (Fab) heavy and light chains. Nucleic Acids Res 19: 4133-4137

Hoogenboom HR, Lutgerink JT, Pelsers MM, Rousch MJ, Coote J, van Neer N, de Bruine A, Van Nieuwenhoven FA, Glatz JF, Arends JW (1999) Selection-dominant and non-accessible epitopes on cell-surface receptors revealed by cell-panning with a large phage antibody library. Eur J Biochem 260: $774-784$

Kickhoefer VA, Rajavel KS, Scheffer GL, Dalton WS, Scheper RJ, Rome LH (1998) Vaults are up-regulated in multidrug-resistant cancer cell lines. $J$ Biol Chem 273: $8971-8974$

Kickhoefer VA, Siva AC, Kedersha NL, Inman EM, Ruland C, Streuli M, Rome LH (1999b) The 193-kD vault protein, VPARP, is a novel poly (ADP-ribose) polymerase. J Cell Biol 146: 917-928 
Kickhoefer VA, Stephen AG, Harrington L, Robinson MO, Rome LH (1999a) Vaults and telomerase share a common subunit, TEP1. J Biol Chem 274: $32712-32717$

Kitazono M, Sumizawa T, Takebayashi Y, Chen ZS, Furukawa T, Nagayama S, Tani A, Takao S, Aikou T, Akiyama S (1999) Multidrug resistance and the lung resistance-related protein in human colon carcinoma SW-620 cells. J Natl Cancer Inst 91: 1647-1653

Kuiper CM, Broxterman HJ, Baas F, Schuurhuis GJ, Haisma HJ, Scheffer GL, Lankelma J, Pinedo HM (1990) Drug transport variants without P-glycoprotein overexpression from a human squamous lung cancer cell line after selection with doxorubicin. J Cell Pharmacol 1: 35-41

Laurencot CM, Scheffer GL, Scheper RJ, Shoemaker RH (1997) Increased LRP mRNA expression is associated with the MDR phenotype in intrinsically resistant human cancer cell lines. Int J Cancer 72: 1021-1026

LeCerf JM, Shirley TL, Zhu Q, Kazantsev A, Amersdorfer P, Housman DE, Messer A, Huston JS (2001) Human single-chain Fv intrabodies counteract in situ huntingtin aggregation in cellular models of Huntington's disease. Proc Natl Acad Sci USA 98: 4764-4769

Lener M, Horn IR, Cardinale A, Messina S, Nielsen UB, Rybak SM, Hoogenboom HR, Cattaneo A, Biocca S (2000) Diverting a protein from its cellular location by intracellular antibodies. The case of p21Ras. Eur Biochem 267: 1196-1205

Marks JD, Hoogenboom HR, Bonnert TP, McCafferty J, Griffiths AD, Winter G (1991) By-passing immunization. Human antibodies from V-gene libraries displayed on phage. J Mol Biol 222: 581-597

Poloni F, Palumbo S, Cianfriglia M, Felici F (1995a) Selection of phagedisplayed peptides mimicking an extracellular epitope of human MDR1P-glycoprotein. Physiol Chem Physics Med NMR 27: $271-280$

Poloni F, Romagnoli G, Cianfriglia M, Felici F (1995b) Isolation of antigenic mimics of MDR1-P-glycoprotein by phage-displayed peptide libraries. Int J Cancer 61: 727-731

Popkov M, Lussier I, Medvedkine V, Esteve PO, Alakhov V, Mandeville R (1998) Multidrug-resistance drug-binding peptides generated by using a phage display library. Eur J Biochem 251: $155-163$

Scheffer GL, Schroeijers AB, Izquierdo MA, Wiemer EAC, Scheper RJ (2000) Lung resistance-related protein/major vault protein and vaults in multidrug-resistant cancer. Curr Opin Oncol 12: 550-556
Scheffer GL, Wijngaard PL, Flens MJ, Izquierdo MA, Slovak ML, Pinedo HM, Meijer CJ, Clevers HC, Scheper RJ (1995) The drug resistance-related protein LRP is the human major vault protein. Nature Med 1: $578-582$

Scheper RJ, Broxterman HJ, Scheffer GL, Kaaijk P, Dalton WS, van Heijningen TH, van Kalken CK, Slovak ML, de Vries EG, van der Valk P, Meijer CJ, Pinedo HM (1993) Overexpression of a M(r) 110,000 vesicular protein in non-P-glycoprotein-mediated multidrug resistance. Cancer Res 53: $1475-1479$

Schneider E, Paul D, Ivy P, Cowan KH (1999) Multidrug resistance. Cancer Chemother Biol Resp Modif 18: $152-177$

Schroeijers AB, Scheffer GL, Reurs AW, Pijnenborg ACLM, Abbondanza C, Wiemer EAC, Scheper RJ (2001) Detection of the Mr 110,000 lung resistance-related protein LRP/MVP with monoclonal antibodies. J Histochem Cytochem 49: 1379-1386

Schroeijers AB, Siva AC, Scheffer GL, de Jong MC, Bolick SC, Dukers DF, Slootstra JW, Meloen RH, Wiemer E, Kickhoefer VA, Rome LH, Scheper RJ (2000) The Mr 193,000 vault protein is up-regulated in multidrug-resistant cancer cell lines. Cancer Res 60: 1104-1110

Stephen AG, Raval-Fernandes S, Huynh T, Torres M, Kickhoefer VA, Rome LH (2001) Assembly of vault-like particles in insect cells expressing only the major vault protein. J Biol Chem 276: $23217-23220$

Vaughan TJ, Osbourn JK, Tempest PR (1998) Human antibodies by design. Nat Biotechnol 16: $535-539$

Winter G, Griffiths AD, Hawkins RE, Hoogenboom HR (1994) Making antibodies by phage display technology. Annu Rev Immunol 12: 433-455

Zaman GJ, Flens MJ, van Leusden MR, de Haas M, Mulder HS, Lankelma J, Pinedo HM, Scheper RJ, Baas F, Broxterman HJ, Borst P (1994) The human multidrug resistance-associated protein MRP is a plasma membrane drug-efflux pump. Proc Natl Acad Sci USA 91: 8822-8826

Zijlstra JG, de Vries EG, Mulder NH (1987) Multifactorial drug resistance in an adriamycin-resistant human small cell lung carcinoma cell line. Cancer Res 47: $1780-1784$ 